\title{
Pathogenicity of Rhizoctonia solani AG 1-IA on major weeds prevalent in rice and maize ecosystem in Meghalaya
}

\author{
ROW SAVEINAI ${ }^{1}$, PANKAJ BAISWAR ${ }^{1 *}$, RAJESH KUMAR ${ }^{1}$, THANGASWAMY RAJESH ${ }^{2}$ and GAJANAN T. BEHERE ${ }^{1}$ \\ 'ICAR Research Complex for NEH Region, Umiam 793 103, Meghalaya, India \\ ${ }^{2}$ College of Post Graduate Studies, CAU, Umiam 793 103, Meghalaya, India
}

Received: 1 December 2016/ Accepted: 14 February 2017/ Published online: 23 March 2017

(C) Indian Phytopathological Society 2017

\begin{abstract}
Rhizoctonia solani Kühn (Teleomorph: Thanatephorus cucumeris) is an economically important soil borne basidiomycetous pathogen of worldwide distribution. It causes sheath blight disease of rice and banded leaf and sheath blight (BLSB) disease in maize. Twenty three lowland rice weeds and thirty one upland (maize) weeds were collected and used. Rice isolate (SRS) was pathogenic on all the lowland rice and upland weeds. Maize isolate (RSM2) was not pathogenic on Cyperus difformis, C. haspans, C. odoratus, Sagittaria sagittifolia, Celosia argentea, Commelina diffusa and Floscopa scandens. Minimum days for scleriotia formation was 3 days on $C$. bengalensis, maximum sclerotia production was observed on Echinochloa crusgalli (14 nos.) with the isolate SRS. Minimum days for sclerotia formation was 2 days after inoculation on Euphorbia hirta, Fimbristylis dichotoma, Rotala indica and Scirpus juncoides. Maximum sclerotia production was observed on Alternanthera philoxeroides (11 nos.) with the isolate RSM2. Area under disease progress curve was calculated and mean separation was done using REGWQ test (Ryan/Elinot/Gabriel/Welsch procedure). The weeds Ageratum houstonianum (10.2), A. sessilis (14), A. philoxeroides (25.3), Imperata cylindrica (14), Paspalum distichum (17.8) and Ambrosia artemisiifolia (23.3) were susceptible whereas Dactyloctenium aegyptium (115.6), E. colona (115.6) and Bidens pilosa (111.9) were highly susceptible to the isolate SRS. The weed $A$. houstonianum (43.7) was susceptible and $R$. indica (267.4) and $E$. hirta (266.2) were highly susceptible to the isolate RSM2.
\end{abstract}

Key words: AG 1-IA, anastomosis group, pathogenicity test, Rhizoctonia solani

The sheath blight of rice caused by Rhizoctonia solani is currently ranked second after blast disease (Prasad et al., 2010). Banded leaf and sheath blight of maize caused by $R$. solani is one of the most widespread and destructive diseases found in most parts of the world (Rani et al., 2013). The pathogen $R$. solani is a nonobligate, necrotrophic, phytopathogenic basidiomycetous fungus causing severe economic damage to a wide variety of plant species. It has limited movement due to lack of spores and it survives in unfavourable conditions in form of sclerotia or dormant mycelia (Sumner, 1996). Sclerotia can survive for two years in the soil, they may float in permanent flooded conditions and move to nearby fields or within the field through continuous flood irrigation and then they get attached to the plant causing sheath blight disease (Brooks, 2007). R. solani is composed of different anastomosis groups (AGs). Hyphal anastomosis is the traditional method of differentiating and grouping strains. Anastomosis is the fusion of two compatible vegetative hyphae. Based on anastomosis reactions like hyphal fusion, morphology, pathogenicity and physiology, 14 AGs have been identified till date (AG1 to AG13 and AG-BI) (Carling, 1996; Gonzalez et al., 2006; Wang et al., 2015).

The pathogen has worldwide distribution and is known to attack at least 188 species of higher plants,

${ }^{*}$ Corresponding author: pbaiswar@yahoo.com including crops, vegetables, ornamentals, forest trees and turfgrasses (Lakshman and Amaradasa, 2014). In different agro-climatic regions of India, several weeds and cultivated plant species are known to act as alternate and collateral hosts of $R$. solani (Singh et al., 2012).

Present study was taken up to understand the pathogenicity of AG1-IA on weed hosts, which in turn would make possible to evolve novel strategies to control sheath blight disease on rice, maize and several other crops of agricultural importance.

\section{MATERIALS AND METHODS}

Samples infected with $R$. solani which exhibited sheath blight and banded leaf and sheath blight symptoms on rice and maize, respectively were collected and isolation was done following the method described by Mahendra et al. (2016) with minor modifications (antibiotic Chloramphenicol @ $50 \mathrm{mg} / \mathrm{l}$ was suspended in $10 \mathrm{ml}$ of 95\% alcohol then it was mixed with one liter of media before sterilization). Pure cultures were obtained by cutting hyphal tips from the periphery of actively grown 3-day old cultures and were transferred to PDA slants. Thereafter, isolates were designated as SRS and FRS, both obtained from rice, RSM1 and RSM2, both obtained from maize for use in further studies. 


\section{Initial pathogenicity test of rice and maize isolates}

Pathogenicity was confirmed by inoculation of rice isolates SRS and FRS and maize isolates RSM1 and RSM2 on maize variety (DA-61A) and on rice variety (HR12) using the method described by Mahendra et al. (2016).

\section{Molecular characterization of $\boldsymbol{R}$. solani isolates by using specific primers}

The DNA extraction and PCR was done following the methods (with minor modifications) mentioned by Mahendra et al. (2016). Presence of specific bands using specific primers was used as criteria for identification of anastomosis groups and subgroups of $R$. solani (Matsumoto, 2002; Sayler and Yang, 2007). One isolate (SRS) was sequenced after obtaining the product using universal primers for ITS region (ITS 5 and 4) (White et al., 1990). The sequence was deposited in GenBank. Using BLASTn similarity search was performed. Sequences of other AGs were downloaded from NCBI and included in the phylogenetic analysis. The "Maximum Parsimony (MP)" analysis was done using the Subtree pruning and regrafting algorithm in which the initial trees were obtained with the random addition of sequences (Tamura et al., 2013). Nodal support was calculated using one thousand bootstrap replicates (Felsenstein, 1985) and the ITS sequence of Athelia rolfsii (AY684917) was used as root.

\section{Pathogenicity of $\boldsymbol{R}$. solani isolates on major weeds of lowland rice}

Major lowland weeds prevalent in and around paddy field, water channel and irrigation ponds were collected. For pathogenicity test, detached leaves of weeds were used. Three days old culture of SRS and RSM2 isolates of $R$. solani were used for inoculation, incubated at $27 \pm 1^{\circ} \mathrm{C}$ and examined regularly for appearance of symptoms and production of sclerotia.

\section{Pathogenicity test of $\boldsymbol{R}$. solani on major weeds of maize}

Major upland weeds prevalent in and around the maize field and upland paddy field were collected. The pathogenicity test was carried out using isolates SRS and RSM2 on detached leaves of weeds. After inoculation symptom appearance was checked regularly and per cent infected area was recorded on all replicates. Production of sclerotia was also observed and recorded after inoculation.

\section{Pathogenicity test on different crops}

Eight different crops namely ginger (Zingiber officinale), groundnut (Arachis hypogaea), turmeric (Curcuma longa), soyabean (Glycine max), cowpea (Vigna unguiculata), red gram (Cajanus cajan), wild ginger ( $C$. angustifolia) and mesta (Hibiscus sabdariffa) commonly cultivated in vegetable garden were collected. The pathogenicity test was carried out on apparently healthy detached leaves of crops using both the isolates SRS and RSM2. Symptom occurrence was checked regularly after inoculation and per cent infected area was recorded.

\section{Statistical analysis}

Statistical analysis was done using SPSS 20.0 software. The area under disease progress curve (AUDPC) was calculated using the following formula.

$$
\text { AUDPC }=\sum_{i=1}^{k} \frac{1}{2}\left(S_{i}+S_{i-1}\right)\left(t_{i+1}-t_{1}\right)
$$

\section{RESULTS AND DISCUSSION}

\section{Molecular characterization}

Four isolates were identified by PCR amplification using specific primers. All the isolates belonged to AG 1-IA. Based on amplification with specific primers and band sizes the isolates were identified as AG 1-IA ( 265 bp and $\sim 140$ bp). The isolates RSM2, RSM1 and SRS gave a band size of $265 \mathrm{bp}$. In case of isolate FRS, the band size was $\sim 140$ bp since second primer set for identification of AG 1-IA was used. The ITS region of one isolate (SRS) was obtained using universal primers (ITS 5 and 4) and the sequence has been deposited in GenBank (KX132899). Similarity searches using Blastn showed $100 \%$ similarity with AG 1-IA sequences. Phylogenetic analysis using maximum parsimony also grouped it with AG 1-IA with 100\% bootstrap support (Fig. 1).

Matsumoto (2002) and Saylor and Yang (2007), have designed specifically primed PCR for direct detection of AG 1 and $A G 2$ subgroups and using these primers, the four isolates SRS, FRS, RSM1 and RSM2 were identified as AG 1 IA. Baiswar et al. (2012 and 2014) have also identified AG 1-IA on rice and maize, and AG 1 IB on soybean, marigold using the primers developed by Matsumoto (2002) and Saylor and Yang (2007).

\section{Initial pathogenicity test with rice and maize isolates}

Prominent symptoms on the inoculated leaf sheaths of rice were observed after 4 days of inoculation on both the replicates. Whereas, in case of maize, symptoms on the inoculated leaves were observed after 2 days of inoculation on both the replicates. The rice isolate SRS was more virulent than FRS and maize isolate RSM2 was more virulent than RSM 1. So, SRS and RSM2 were used for further pathogenicity test on lowland rice and maize weeds.

\section{Pathogenicity test of $\boldsymbol{R}$. solani isolates on major weeds of lowland rice}

The isolate SRS was pathogenic on all weeds as shown in the Table 1. The isolate RSM2 was found to be pathogenic on all weeds except $C$. difformis, $C$. haspans, C. odoratus and S. sagittifolia. 


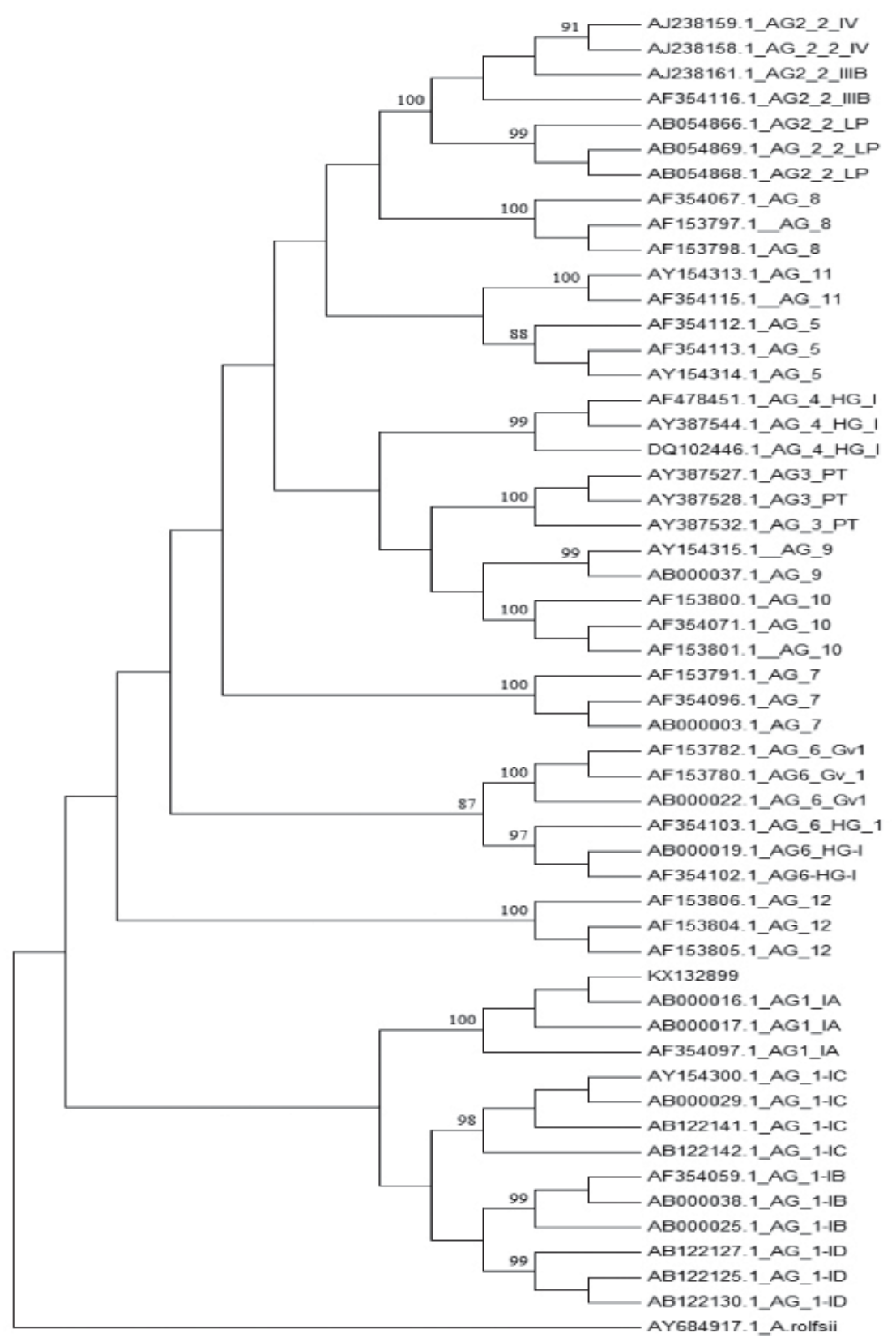

Fig. 1. Maximum parsimony tree obtained using subtree pruning and regrafting algorithm

Although both the isolates belonged to AG 1-IA, this difference in pathogenicity may be due to high intra-group variability among the subgroup according to Susheela and Reddy (2013). Moni et al. (2016) observed significant genetic variation within the isolates of $R$. solani collected from similar agro-ecological regions of Bangladesh. This study revealed that $R$. solani has the ability to infect wide range of weeds and these weeds act as alternate host of $R$. solani. Similar findings have also been reported earlier by Acharya and Sengupta (1998), Sivalingam et al. (2006) and Lenka et al. (2014). They found weeds like Amaranthus viridis, Commelina benghalensis, Cynodon dactylon, Dactyloctenium aegyptium, Digitaria ciliaris, Echinochloa colona, Euphorbia hirta, Fimbristylis miliaceae etc. as alternate host of $R$. solani. Mareeswari et al. (2004) have also reported that the weeds like $C$. dactylon, E. crusgalli, Marsilea quadrifoliata and Typha angustata are highly susceptible to infection by R. solani.

Pathogenicity test of $\boldsymbol{R}$. solani on major weeds of maize

The isolate SRS was pathogenic on all the weeds as shown in Table 2. The isolate RSM2 was pathogenic on all weeds except $C$. argentea, $C$. diffusa and $F$. miliacea (Fig. 2).

Khandaker et al. (2008) also tested pathogenicity of two $R$. solani isolates on 33 different hosts and they observed differences in the degree of pathogenicity among the hosts. 
Table 1. Pathogenicity test on weeds of lowland rice

\begin{tabular}{|c|c|c|}
\hline Scientific name & $\begin{array}{l}\text { Pathogenecity } \\
\text { test with rice } \\
\text { isolates } \\
\text { (SRS) }\end{array}$ & $\begin{array}{c}\text { Pathogenecity } \\
\text { test with maize } \\
\text { isolates } \\
\text { (RSM2) }\end{array}$ \\
\hline Alternanthera philoxeroides & + & + \\
\hline Brachiaria mutica & + & + \\
\hline Bulbostylis densa & + & + \\
\hline Commelina benghalensis & + & + \\
\hline Cynodon dactylon & + & + \\
\hline C. difformis & + & - \\
\hline C. haspans & + & - \\
\hline C. iria & + & + \\
\hline C. odoratus & + & - \\
\hline C. pilosus & + & + \\
\hline Echinochloa colona & + & + \\
\hline E. crusgalli & + & + \\
\hline Eleocharis congesta & + & + \\
\hline Emilia sonchifolia & + & + \\
\hline Eragrostis unioloides & + & + \\
\hline Euphorbia hirta & + & + \\
\hline Fimbristylis dichotoma & + & + \\
\hline F. miliacea & + & + \\
\hline Monochoria vaginalis & + & + \\
\hline Paspalum dilatatum & + & + \\
\hline Rotala indica & + & + \\
\hline Sagittaria sagittifolia & + & - \\
\hline Scirpus juncoides & + & + \\
\hline
\end{tabular}

+ pathogenic, - non pathogenic

The findings of the present study confirmed that the pathogen could reside in the weeds of maize and these infected weeds could act as a source of inoculum. So, it is recommended to remove the weed hosts to reduce the inoculum potential. Gokulapalan and Nair (1983) also found pathogen $R$. solani residing in weed hosts viz. Alternanthera philoxeroides, C. iria, E. colona and E. crusgalli and revealed the importance of weed control which would reduce plant competition and also increase the yield.

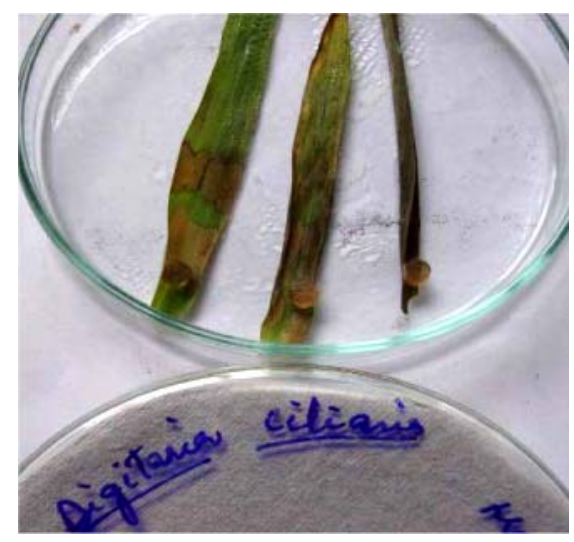

Fig. 2. Pathogenicity test with isolate RSM2 on weed Digitaria ciliaris
Table 2. Pathogenicity test on weeds of maize

\begin{tabular}{|c|c|c|}
\hline Scientific name & $\begin{array}{l}\text { Pathogenicity } \\
\text { test with rice } \\
\text { isolates } \\
\text { (SRS) }\end{array}$ & $\begin{array}{l}\text { Pathogenecity } \\
\text { test with maize } \\
\text { isolates } \\
\text { (RSM2) }\end{array}$ \\
\hline Ageratum houstonianum & + & + \\
\hline Alternanthera sessilis & + & + \\
\hline Amaranthus spinosus & + & + \\
\hline Ambrosia artemisiifolia & + & + \\
\hline Ammannia baccifera & + & + \\
\hline Bidens pilosa & + & + \\
\hline Celosia argentea & + & - \\
\hline Commelina benghalensis & + & + \\
\hline C. diffusa & + & - \\
\hline Crassocephalum crepidioides & + & + \\
\hline Cuphea balsamona & + & + \\
\hline Cynodon dactylon & + & + \\
\hline Cyperus iria & + & + \\
\hline Cyrtoccum accrescens & + & + \\
\hline Dactyloctenium aegyptium & + & + \\
\hline Digitaria adscendens & + & + \\
\hline D. ciliaris & + & + \\
\hline Echinochloa colona & + & + \\
\hline E. crusgalli & + & + \\
\hline Eleusine indica & + & + \\
\hline Euphorbia hirta & + & + \\
\hline Fimbristylis dichotoma & + & + \\
\hline F. miliacea & + & + \\
\hline Floscopa scandens & + & - \\
\hline Galinsoga parviflora & + & + \\
\hline Imperata cylindrica & + & + \\
\hline Ischaemum rugosum & + & + \\
\hline Oplismenus composites & + & + \\
\hline Paspalum distichum & + & + \\
\hline Setaria glauca & + & + \\
\hline Spilanthes acmella & + & + \\
\hline
\end{tabular}

+ pathogenic, - non pathogenic

\section{Sclerotial count and days required for sclerotia formation on lowland rice and maize weeds with rice isolate (SRS)}

Sclerotial count was recorded after inoculation with the $\mathrm{SRS}$ isolate. Number of sclerotia production ranged from 1 to 14 as shown in the Fig 3. The isolate SRS showed great variation in time taken for sclerotia formation, which ranges from 3 to 7 days after inoculation as shown in Fig 3.

Debbarma and Dutta (2015) also observed great variation in time taken for sclerotia formation. It ranged from 9 to 18 days with $R$. solani isolates obtained from rice, maize, cowpea, greengram and pepper. Singh et al. (2015) also observed variation in no. of sclerotia produced by different isolates of $R$. solani obtained from maize, rice, potato, mungbean and urd bean. Similarly, Singh et al. (2015) also reported that $R$. solani isolates showed great variation in the time taken for sclerotia 


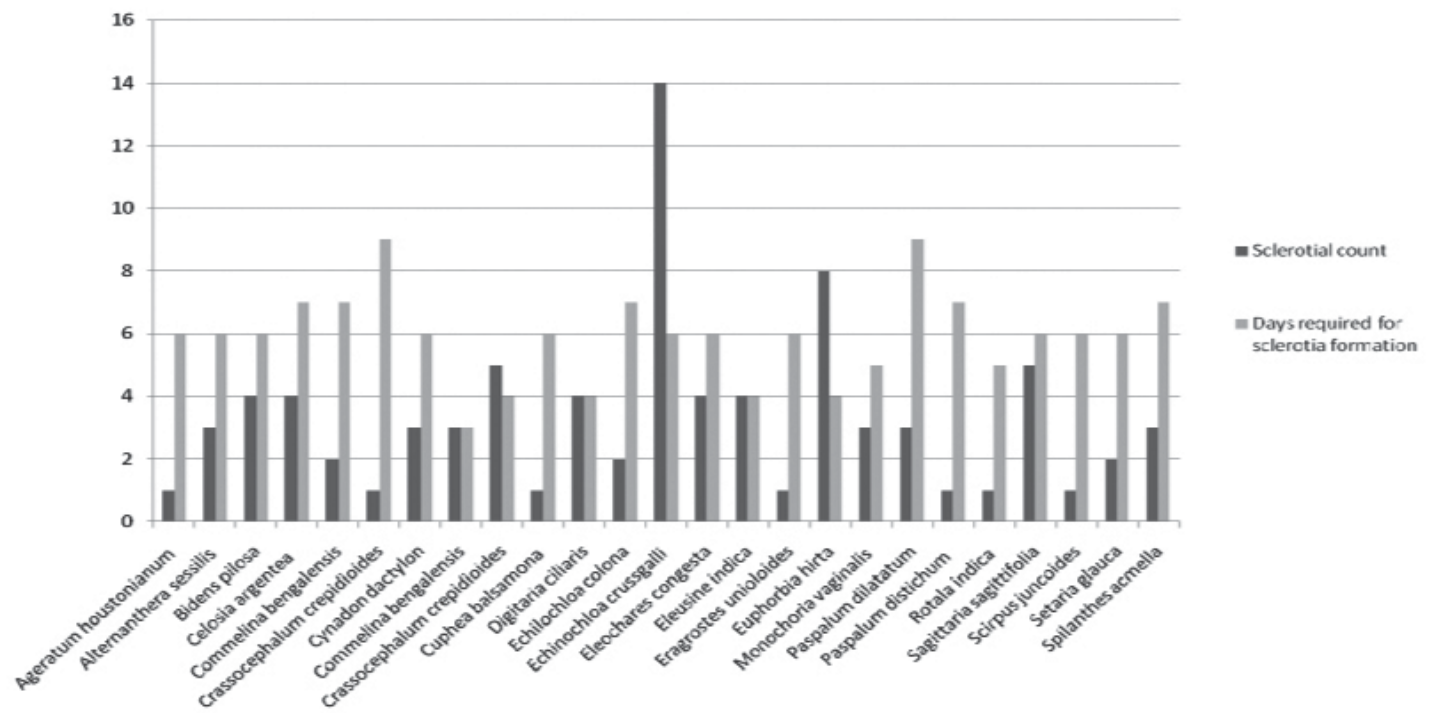

Fig. 3. Sclerotial count and days required for sclerotia formation on weeds with rice isolate (SRS)

formation which ranged from 3 to 6 days. Previous finding indicates that in tropical environment sheath blight pathogen $R$. solani survives through sclerotia from one crop season to another and mycelia through weed hosts and in plant debris (Kobayashi et al., 1997). So, it is necessary to remove the weed hosts.

\section{Sclerotial count and days required for sclerotia formation on lowland rice and maize weeds with maize isolate (RSM2)}

Sclerotial count was recorded after inoculation with isolate RSM2. Number of sclerotia production ranged from 1 to 11 as shown in Fig 4. The isolate RSM2 showed variation in time taken for sclerotia formation, which ranged from 2 to 6 days after inoculation.
Variation in number of sclerotia production has been also documented by Singh et al. (2015) using different isolates of $R$. solani obtained from maize, rice and potato. Ganeshamoorthi and Dubey (2015) also reported a high variation in number of sclerotia formation, ranging from 1 to 9 with different isolates of chickpea, mungbean and urdbean. Similarly, Meena et al. (2001) also reported that the time taken for sclerotia formation ranged from 3 to 6 days. Variation in time taken for sclerotia formation has also been reported by Singh et al. (2015) using different isolates of $R$. solani obtained from maize, rice and potato.

\section{Pathogenicity test on different crops}

The isolates SRS and RSM2 were used for pathogenicity test on eight different plant species. The isolate SRS was pathogenic on all the plant species (Fig. 5). The isolate

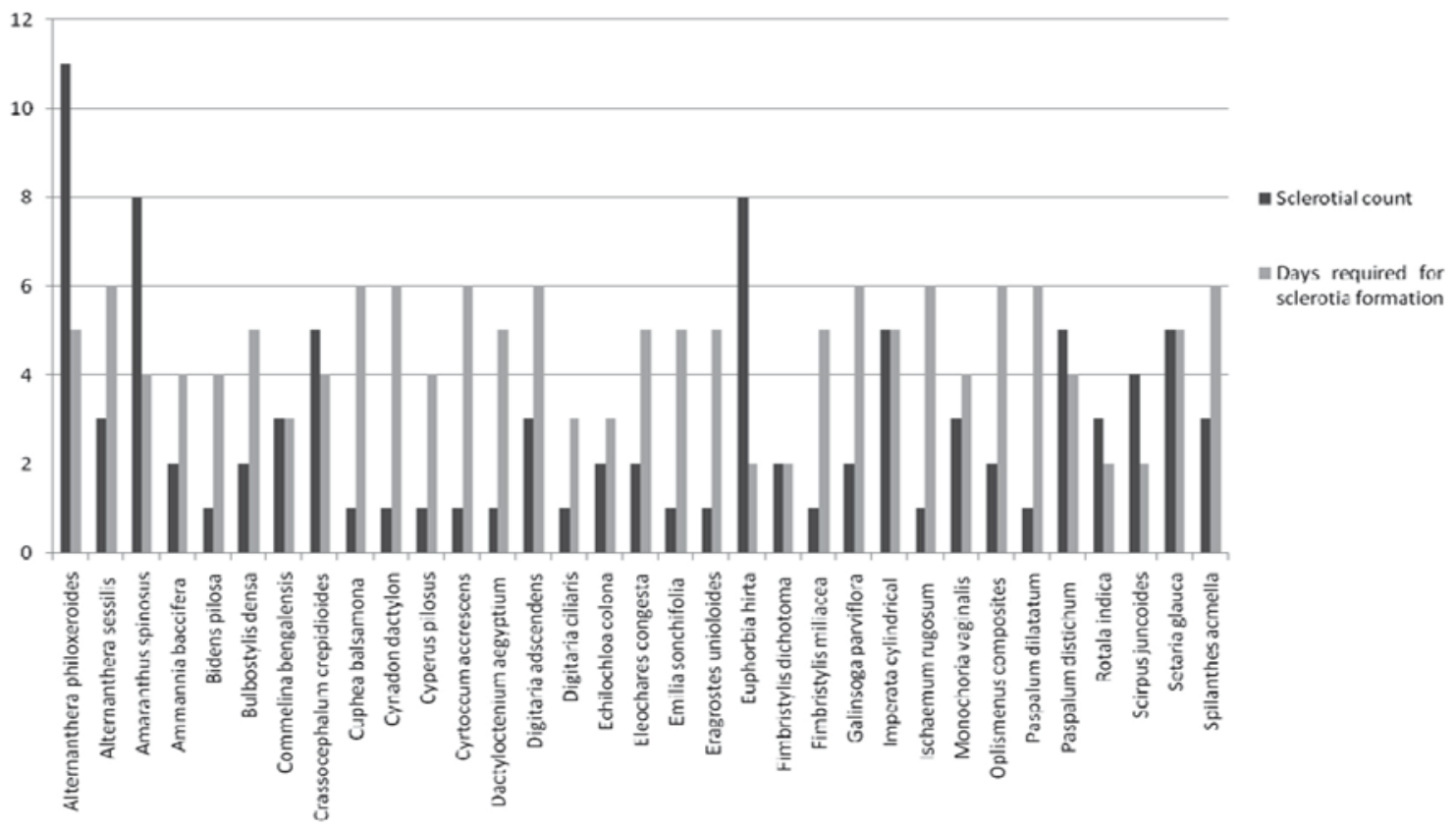

Fig. 4. Sclerotial count and days required for sclerotia formation on weeds with maize isolate (RSM2) 


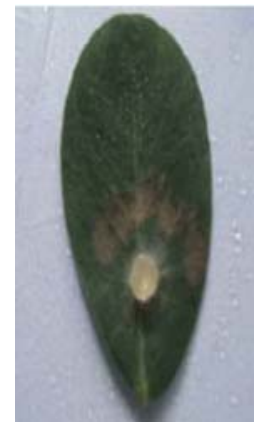

Fig. 5. Pathogenicity test with isolate SRS on Groundnut

RSM2 was pathogenic on V. unguiculata, $H$. sabdariffa, $C$. cajan and $C$. angustifolia but it was not able to infect four crops viz., Z. officinale, A. hypogaea, G. max and $C$. longa.

Many other research workers like Acharya and Sengupta (1998), Gokulapalan and Nair (1983), Meena and Muthusamy (1998) and Nelson et al. (1996) have also reported groundnut, sugarbeet, dry bean, mustard, sunflower and flux seedlings etc. as collateral hosts of the sheath blight pathogen.

\section{Susceptibility analysis using AUDPC of lowland rice and maize weeds with rice isolate (SRS)}

The results revealed that weeds namely, Ageratum houstonianum (10.2), A. sessilis (14), A. philoxeroides (25.3), Imperata cylindrica (14), Paspalum distichum

Table 3. AUDPC of weeds inoculated with rice isolate (SRS)

\begin{tabular}{lc}
\hline Scientific name & AUDPC* \\
\hline Ageratum houstonianum & $10.2^{\mathrm{a}}$ \\
Alternanthera sessilis & $14.0^{\mathrm{a}}$ \\
Amaranthus spinosus & $55.2^{\mathrm{bc}}$ \\
Ambrosia artemisiifolia & $23.3^{\mathrm{a}}$ \\
Ammannia baccifera & $44.1^{\mathrm{b}}$ \\
Bidens pilosa & $111.9^{\mathrm{h}}$ \\
Commelina benghalensis & $80.2^{\mathrm{ef}}$ \\
C. diffusa & $76.1^{\mathrm{de}}$ \\
Dactyloctenium aegyptium & $115.6^{\mathrm{h}}$ \\
Digitaria adscendens & $93.0^{\mathrm{fg}}$ \\
Echinochloa colona & $115.6^{\mathrm{h}}$ \\
Fimbristylis dichotoma & $75.7^{\mathrm{de}}$ \\
Imperata cylindrica & $14.0^{\mathrm{a}}$ \\
Oplismenus composites & $93.0^{\mathrm{fg}}$ \\
Paspalum distichum & $17.8^{\mathrm{a}}$ \\
Setaria glauca & $93.0^{\mathrm{fg}}$ \\
Alternanthera philoxeroides & $25.3^{\mathrm{a}}$ \\
Brachiaria mutica & $105.9^{\mathrm{gh}}$ \\
Bulbostylis densa & $93.0^{\mathrm{gg}}$ \\
Cyperus odoratus & $102.7^{\mathrm{gh}}$ \\
Eragrostis unioloides & $64.7^{\mathrm{cd}}$ \\
Scirpus juncoides & $59.8^{\mathrm{c}}$ \\
\hline A &
\end{tabular}

*Arcsine transformed values

Means within a column with same letters are not significantly different according to REGWQ test $(p=0.05)($ Ryan/Einot/Gabriel/ Welsch procedure)
(17.8) and Ambrosia artemisiifolia (23.3) which are statistically at par were least susceptible whereas $D$. aegyptium (115.6), E. colona (115.6) and Bidens pilosa (111.9) were at par and highly susceptible to the isolate SRS (Table 3).

\section{Susceptibility analysis using AUDPC of lowland rice and maize weeds with maize isolate (RSM2)}

The results revealed that the weed $A$. houstonianum (43.7) was least susceptible whereas weeds like Rotala indica (267.4) and E. hirta (266.2) were highly susceptible and statistically at par, using AUDPC criteria (Table 4).

Adhipathi et al. (2013) have used this criteria for identifying susceptibility against sheath blight of rice. The AUDPC is considered important since it provides an estimate for disease progress overtime rather than just the final severity.

It can be concluded from the present study that most of the upland and lowland weeds are susceptible to $R$. solani AG 1-IA but few are highly susceptible and these highly susceptible weeds should not be used as mulching material. Also, removal of these weeds will ultimately help in managing the sheath blight of rice and banded leaf and sheath blight of maize.

Table 4. AUDPC of weeds inoculated with maize isolate (RSM2)

\begin{tabular}{lc}
\hline Scientific name & AUDPC* \\
\hline Ageratum houstonianum & $43.7^{\mathrm{a}}$ \\
Bidens pilosa & $146.4^{\mathrm{fg}}$ \\
Commelina benghalensis & $171.9^{\mathrm{g}}$ \\
Cynodon dactylon & $115.6^{\mathrm{de}}$ \\
Cyperus iria & $71.3^{\mathrm{abc}}$ \\
Dactyloctenium aegyptium & $93.0^{\mathrm{cd}}$ \\
Digitaria adscendens & $108.1^{\mathrm{d}}$ \\
Echinochloa colona & $155.8^{\mathrm{g}}$ \\
E. crusgalli & $151.8^{\mathrm{g}}$ \\
Eleusine indica & $142.9^{\mathrm{efg}}$ \\
Euphorbia hirta & $266.2^{\mathrm{i}}$ \\
Galinsoga parviflora & $98.3^{\mathrm{cd}}$ \\
Imperata cylindrica & $76.6^{\mathrm{bc}}$ \\
Paspalum distichum & $99.0^{\mathrm{cd}}$ \\
Ammannia baccifera & $160.8^{\mathrm{g}}$ \\
Alternanthera philoxeroides & $119.3^{\mathrm{def}}$ \\
Bulbostylis densa & $93.0^{\mathrm{cd}}$ \\
Cyperus pilosus & $205.2^{\mathrm{h}}$ \\
Emilia sonchifolia & $108.1^{\mathrm{d}}$ \\
Eragrostis unioloides & $120.9^{\mathrm{def}}$ \\
Paspalum dilatatum & $49.9^{\mathrm{ab}}$ \\
Scirpus juncoides & $267.4^{\mathrm{i}}$ \\
\hline Arcsine tans & $164.7^{\mathrm{g}}$ \\
\hline
\end{tabular}

*Arcsine transformed values

Means within a column with same letters are not significantly different according to REGWQ test $(p=0.05)($ Ryan/Einot/Gabriel/ Welsch procedure) 


\section{ACKNOWLEDGEMENTS}

The authors are grateful to the Director, ICAR Research Complex for NEH Region, Umiam, Meghalaya for providing facilities and to the Dean, CPGS (Central Agricultural University), Meghalaya for support.

\section{REFERENCES}

Acharya S and Sengupta PK (1998). Collateral hosts of rice sheath blight fungus, Rhizoctonia solani. Oryza 35: 8990.

Adhipathi P, Singh V and Meena SC (2013). Virulence diversity of Rhizoctonia solani causing sheath blight disease in rice and its host pathogen interaction. Bioscan 8: 949-952.

Baiswar P, Bag TK, Basumatary R, Chandra S and Ngachan SV (2012). Molecular evidence reveals presence of Rhizoctonia solani AG 1-IB on Tagetes patula in India. Australas. Plant Dis. Notes 7: 63-66.

Baiswar P, Ngachan SV, Kipgen TL, Das A, Chandra S, Patel DP and Rajkhowa DJ (2014). Molecular characterization of Rhizoctonia solani on rice, maize and soybean in northeast India. J. Eco-Friendly Agriculture 9: 61-64.

Brooks SA (2007). Sensitivity to a phytotoxin from Rhizoctonia solani correlates with sheath blight susceptibility in rice. Phytopathology 97: 1207-1212.

Carling DE (1996). Grouping of Rhizoctonia solani by hyphal anastomosis reaction. In Rhizoctonia species: Taxonomy, molecular biology, ecology, pathology and disease control, edited by Sneh B, Jabaji-Hare S, Neate S and Dijst G Boston: Kluwer Academic Publisher, doi: 10.1007/978-94017-2901-73.

Debbarma M and Dutta P (2015). Cultural and morphological variability in Rhizoctonia solani isolates of different hosts of Assam. Indian J. Appl. Res. 5: 878-883.

Felsenstein J (1985). Confidence limits on phylogenies: an approach using the bootstrap. Evolution 39: 783-791.

Ganeshamoorthi P and Dubey SC (2015). Morphological and pathogenic variability of $R$. solani isolates associated with wet root rot of chickpea in India. Legume Res. 38: 389-395.

Gokulapalan C and Nair MC (1983). Collateral hosts of Rhizoctonia solani Kühn causing sheath blight of rice. Int. Rice Res. New. 8: 10.

Gonzalez GV, Onco MAP and Rubio Susan V (2006). Review. Biology and systematics of the form genus Rhizoctonia. Span. J. Agric. Res. 4: 55-79.

Khandaker MM, Khair A and Bhuiyan MKA (2008). Disease reaction of different crops against virulent potato isolates of Rhizoctonia solani Kühn. Bangladesh J. Bot. 37: 75-80.

Kobayashi T, Mew TW and Hashiba T (1997). Relationship between incidence of rice sheath blight and primary inoculum in the Philippines: Mycelia in plant debris and sclerotia. Ann. Phytopathol. Soc. Jpn. 63: 324-327.

Lakshman D and Amaradasa BS (2014). The pathogen biology, identification and management of Rhizoctonia species with emphasis on isolates infecting turfgrasses. Indian Phytopath. 67: 327-345.

Lenka S, Pun KB, Saha MS and Rath NC (2014). Studies on the host range of Rhizoctonia solani Kuhn causing sheath blight disease in rice. Oryza 51: 100-102.
Mahendra K, Baiswar P, Chandra S, Choudhury BU, Majumder D, Rajesh T and Firake DM (2016). Molecular characterization and influence of soil factors on Rhizoctonia solani in Meghalaya. Indian Phytopath. 69: 271-277.

Mareeswari P, Seetharaman K, Mohan L, Kamalakannan A, Rajinomala N, Karuppiah R and Chitra K (2004). Host range of Rhizoctonia solani inciting rice sheath blight disease. Indian Phytopath. 57: 349.

Matsumoto M (2002). Trials of direct detection and identification of Rhizoctonia solani AG1 and AG2 subgroups using specifically primed PCR analysis. Mycoscience 43: 185189.

Meena B and Muthuswamy M (1998). Host range of Rhizoctonia solani, the incitant of sheath blight disease of rice. Ind. J. Plant Prot. 26: 62-63.

Moni ZR, Ali MA, Alam MS, Rahman MA, Bhuiyan MR, Mian MS, Iftekharuddaula KM, Latif MA and Khan MAI (2016). Morphological and genetical variability among Rhizoctonia solani isolates causing sheath blight disease of rice. Rice Sci. 23: 42-50.

Nelson B, Helms T, Christianson T and Kural I (1996). Characterisation and pathogenicity of Rhizoctonia from soyabean. Plant Dis. 80: 74-80.

Prasad D, Singh R and Singh A (2010). Management of sheath blight of rice with integrated nutrients. Indian Phytopath. 63: $11-15$.

Rani VD, Reddy PN and Devi GU (2013). Banded leaf and sheath blight of maize incited by Rhizoctonia solani f.sp sasakii and its management review. Int. J. Appl. Biol. Pharm. Technol. 4: 52-60.

Sayler RJ and Yang Y (2007). Detection and quantification of Rhizoctonia solani AG 1-IA, the rice sheath blight pathogen, in rice using real-time PCR. Plant Dis. 91: 16631668.

Singh LJ, Geetika G, Jyoti J, Singh HM and Singh SJ (2012). Identification of Rhizoctonia species associated with sheath blight complex in rice. Plant Dis. Res. 27: 258.

Singh R, Murti S, Mehilalm, Tomer A and Prasad D (2015). Virulence diversity in Rhizoctonia Solani causing sheath blight in rice. J. Plant Pathol. Microbiol. 6: 296.

Sivalingam PN, Vishwakarma SN and Singh US (2006). Role of seed-borne inoculum of Rhizoctonia solani in sheath blight of rice. Indian Phytopath. 59: 445-452.

Sumner DR (1996). Sclerotia formation by Rhizoctonia species and their survival: Taxonomy, molecular biology, ecology, pathology and disease control. Kluwer Academic Publishers, Dordrecht, NL.

Susheela K and Reddy CS (2013). Variability in Rhizoctonia solani (AG-1 IA) isolates causing sheath blight of rice in India. Indian Phytopath. 66: 341-350.

Tamura K, Stecher G, Peterson D, Filipski A and Kumar S (2013). MEGA6: molecular evolutionary genetics analysis version 6.0. Mol. Biol. Evol. 30: 2725-2729.

Wang L, Liu LM, Hou YX, Li L and Huang WS (2015). Pathotypic and genetic diversity in the population of Rhizoctonia solani AG1-IA causing rice sheath blight in China. Plant Pathol. 64: 718-728. 